\title{
StUdents' METACOGNITION AND SELF-REgUlated LEARNING: An AnAlysis Through Students' Work in SOlVING HOTS Problem
}

\author{
Imas Ismayati $^{1)}$, Nani Ratnaningsih ${ }^{2)}$, Supratman ${ }^{3)}$ \\ ${ }^{1)}$ Universitas Siliwangi, Tasikmalaya, Indonesia \\ E-mail: imasismayati.mtsn@gmail.com \\ ${ }^{2)}$ Universitas Siliwangi, Tasikmalaya, Indonesia \\ E-mail: naniratnaningsih@unsil.ac.id \\ ${ }^{3)}$ Universitas Siliwangi, Tasikmalaya, Indonesia \\ E-mail: supratman@unsil.ac.id
}

\begin{abstract}
The aims of this study are to analyze and describe the metacognition of students who have high, moderate, and low Self-Regulated Learning (SLR) in solving Higher Order Thinking Skills (HOTS) type problem. The research method that used was qualitative, research subjects were taken from students who can provide information about the results of their work to obtain complete data and stop when there was no information that can be extracted (saturated data), then obtained 6 people consisting of students who have high, medium, low SLR. The Data collection technique used was the think-aloud method. The data analysis technique used in this study was a model from Miles and Huberman. Based on the data analysis, it can be concluded that: the metacognition of students with high SLR used metacognition in the indicators to compose strategies and monitor actions to the maximum while at the evaluation stage they had not been able to mention other alternatives to solve the problem, the metacognition of students with medium SLR used metacognition to the maximum in the indicators of the stage of compiling strategies but at the monitoring actions they had not been able to interpret the results of the answers and at the stage of evaluation they had not been able to mention other alternatives to solve the problem, the metacognition of students with low SLR had not been able to use metacognition to the maximum. Teachers must pay attention to students' self-regulated learning and metacognition in solving HOTS problems.
\end{abstract}

Keywords: Metacognition; Higher Order Thinking Skills; Self-Regulated Learning

\section{INTRODUCTION}

Metacognition is the knowledge and awareness of a person about thinking processes and their ability to it. This ability is very important especially for the purposes of efficient cognitive used in solving problems. The components of metacognition consist of three elements, namely developing strategies or action plans, monitoring or controlling actions, and evaluating or evaluating actions. Students who have good metacognition skills in solving problems will have a good impact on the learning process and achievement as explained by Hofer \& Pintrich (Ormrod, 2008) that the more students know about their thinking and learning processes, the greater their metacognition awareness and the better the learning process and achievements they might achieve. Cognitive psychologists stated that students need to be trained to develop metacognition in effectively solving problems (Desoete, 2007; Özsoy \& Ataman, 2017). Based on observations of VIIIF grade students of MTsN 1 Pangandaran for 2 weeks of 6 lessons, it was found that students lack metacognition abilities. This is indicated by the students who pay attention well when learning but when the test cannot solve the problem. This shows that metacognition is lacking. This finding is reinforced by the research of Alfiyah and Siswono (2014) which concluded that students of class VIII $\mathrm{H}$ of SMP Negeri 1 Puri in Academic Year 2013/2014 have not been able to use their metacognition properly in solving mathematical problems. Another problem that researchers obtained is related to solving mathematical problems, there are students who when asked to do work on the board find it difficult to explain how they get the answers. In line with the 
results of Bulu, Budiyono and Slamet (2015) in their research on metacognition difficulties in SMA Negeri 1 Soe that melancholic, choleric, sanguine, and phlegmatic students have difficulty in using their meta-logic in solving mathematical problems in material opportunities.

According to Supratman, Kosasih and Hermanto (2018) that solving a problem is very important to be instilled in students, the difficulty of solving this problem certainly needs to be adjusted to the level of students in solving a problem There are studies that show metacognition plays an important role in cognitive activities in solving problems (Anggo, 2011; Balk, 2010; Garrett, Mazzocco, \& Baker, 2006). Ratnaningsih, Hidayat, and Akbar (2018) that if it is seen from the depth or complexity of the mathematical activities involved, mathematical thinking can be classified into two types namely Lower Other Thinking Skills and Higher Other Thinking Skills. Thinking skills are fundamental to the education process. A thought can affect learning ability, speed, and effectiveness of learning. HOTS is a way of thinking that is higher than memorizing facts, articulating facts, or applying rules, formulas, and procedures (Thomas \& Thorne, 2009). HOTS questions do not mean difficult or convoluted questions, but questions that are arranged proportionally and systematically (Arifin, 2017). The characteristics of HOTS are (1) evaluation with criteria; (2) shows skepticism; (3) using logical analysis; (4) systematic (Ernawati, 2016). The use of HOTS questions in learning is expected to develop the ability to think critically in solving the problems of the students. The term independence learns the belief in the ability of a person to solve problems without special help from others and an unwillingness to be controlled by others. The relationship between metacognition and SLR can be referred to from the opinions of several experts including (Schraw, Crippen, \& Hartley, 2006; Winne \& Perry, 2000; Zimmerman, 1990) argue that SLR is also related to metacognition. Students who have SLR will be able to plan, make goals, monitor themselves, and evaluate themselves. This ability is a reflection of students who have good metacognition skills. SLR will develop learning situations that apply the development of metacognitive abilities. Self-Regulated Learning according to Amir and Risnawati (2016) is an attempt to carry out learning activities alone or with the help of others, based on his motivation to master a certain material and competence so that it can be used to solve problems.

\section{Methodology}

The research method used in this study was the qualitative research method. Sugiyono (2017) stated that the qualitative research method is a research method used to examine natural object conditions, (as opposed to experiments) where researchers are key instruments, data collection techniques are carried out triangulated, data analysis is inductive, and research results Qualitatively emphasize meaning rather than generalization. This research was conducted in MTsN 1 Pangandaran. The subjects were six subjects; male students who had high learning independence (MT1), female students who had high learning independence (MT2), male students who had moderate learning independence (MS1), female students who had moderate learning independence (MS2), male students who had low learning independence (MR1), and female students who had low learning independence (MR2). The object of this study was the analysis of the metacognition of students in solving HOTS type problems in the material of flat side space in terms of learning independence.

The data collection technique in this study used thinkaloud. According to Someren, Barnard, and Sandberg (1994), think-aloud is a method of thinking hard by asking people to think hard while solving problems and analyzing the resulting verbal protocols. Think-aloud in this study was that students express ideas that are thought of using verbal or spoken sentences in the process of solving mathematical problems so that the data obtained are verbal words and written words. The technique of taking data sources by taking the first person as a sample and then the researcher asks who can provide more information needed. This process continued until the researcher finally gets complete and in-depth data from the data source and stops when there was no information that can be extracted from previous information (saturated data). Data needed in research was collected through questionnaires, tests, and interview results. This research data analysis technique referred to the data analysis model of Miles and Huberman, which was done through data reduction, data presentation, drawing conclusions, and verifying conclusions.

\section{RESULTS AND DISCUSSION}

Metacognition of students who have high learning independence in solving HOTS type problems in the material of flat side space building, when compiling an action plan to solve the problem of flat side space presented, all subjects consisting of 2 students with high learning independence do think-aloud on reading activities after the problem is given. Both subjects are aware of their thought processes by identifying the information provided in the problem by summarizing the information that is important in the problem and verbally re-writing what is written in a different sentence. This can be seen in the snapshot of the results of the MT1 in Fig. 1.

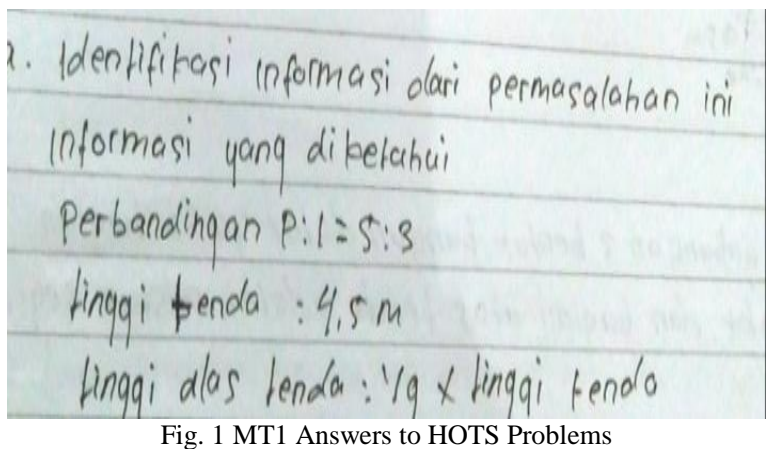

Based on Fig. 1 at the stage of compiling an action plan to solve metacognitive problems of HOTS type material to 
build flat side spaces, subjects MT1 do think-aloud on problem-solving activities. The MT1 subject can identify information provided in the problem which includes known information.

The following are excerpts from the results of the MT1 interview:

Q : After you read the problem in number 1, try to explain what information can you find out from the problem?

MT1: The information is known around the base of the tent is 32 meters, then it is also known that the length and width of the base of the tent are 5: 3, while the height at the bottom of the tent is 1 / (9) times the height of the tent and the height of the tent is 4, 5 meters.

This is in accordance with what Schraw (2006) stated that planning involves choosing the right strategy and allocating resources that affect the learning outcomes and planning activities begin by identifying what is known. Next, the two subjects explore the knowledge that they have previously when interpreting the information that has been identified, namely by mentioning the prerequisites or initial knowledge needed to solve the problem of the subject as well as linking previous concepts that have been learned and that are relevant to the problem to be solved. Then the two subjects make a solution plan that will be done by mentioning the first thing that must be done. In addition, both subjects were able to mention the concepts to be used in solving problems, namely the concept of building a flat side space and the reasons for using the concept and feeling confident being able to solve the given problem by estimating the time limit needed to solve the problem.

When controlling or monitoring their actions, both subjects with high SLR, verifying and clarifying their written answers that were not correct when explaining the steps to solve the problem by making improvements to this answer in accordance with what was stated by Halter (Murtadho, 2013) that monitoring includes activities supervise the learning process, monitor learning with its own questions, provide feedback by completing other ways and maintain concentration and motivation. Both subjects realized the mistakes made in solving the problem after being given a series of metacognitive questions and took the initiative to clarify their incorrect written answers by correcting the answers until the correct answers were obtained. Next, the two subjects identified important information in the problem so that when solving the problem did not make a mistake. The subject identifies the strategy used and classifies related ideas while exploring the reasons for using the strategy when explaining the problem-solving procedure. The subject also developed a solution plan that was compiled by generating new information and stating the problem in the form of drawings. Plan solutions that have been prepared previously in accordance with what has been done. The results of the study showed that the planning that had been prepared previously, was carried out by the two subjects when solving the given problem so that they were able to interpret the results of the formulation of answers obtained by writing the final conclusions that answered the problem in detail.

The answer of the MT2 subjects is aware of her thought processes by evaluating or evaluating the final results obtained whether they are correct and in accordance with the problem or not and making improvements to the answers to obtain the correct problem-solving results. This can be seen from the written work of MT2 subjects in Fig. 2.

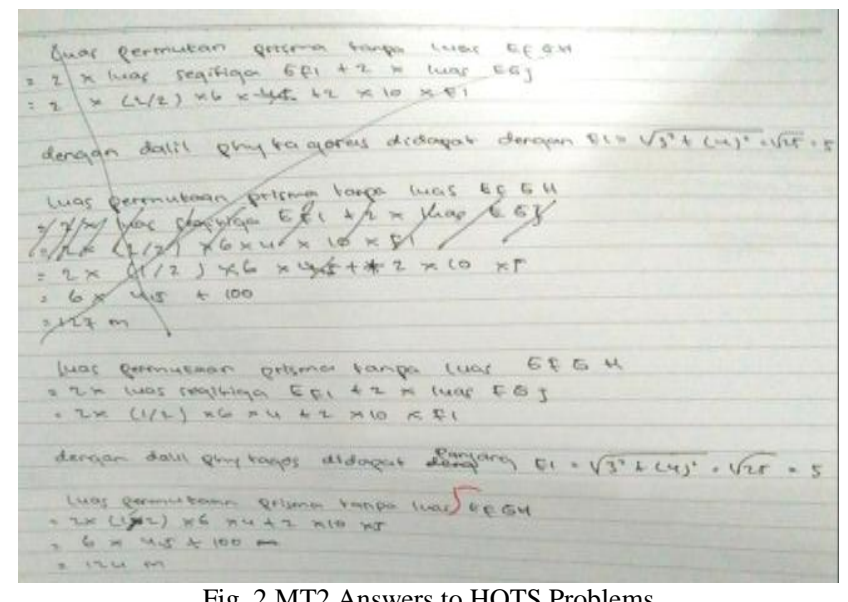

Fig. 2 MT2 Answers to HOTS Problems

This is in accordance with what was stated by Polya (Fitrianti \& Rizal, 2016) that there are two evaluation results that have been made, namely 1) tracing each step of the work done and 2) using other ways to validate the results obtained in the first step. This is because MT2 subjects still have problems in the expected results that need to be corrected for the correct, while MT1 subjects are able to solve problems and obtain the final results that really make them do an assessment of the results of the work he wrote with the results of research produced are correct and the steps used are in accordance with the agreement. The second subject can produce good work results because it is able to obtain the final results obtained correctly and accordingly or not. In addition, compiling them to make mistakes, both subjects immediately solved this error after asking metacognition questions when explaining the problemsolving procedure with high SLR being able to answer all that is meant by the correct end result and also identifying the strategies used. Furthermore, students in the category of high SLR can consistently answer all problems with the correct end result because they can develop their metacognition well so they can successfully solve the given problem. This is in accordance with the opinion of researcher Panaoura (2007) which states that the success of a person in solving a problem is also influenced by his metacognition. In the formal operational stage, metacognition of students who have entered adolescence is expected to be able to provide alternatives to solve problems because according to Piaget (Amir \& Risnawati, 2016), in this period ideally teenagers already have their own mindsets in an effort to solve complex problems and abstract. The subject is only fixated to use the problem-solving steps that have been taught by the teacher. This might be caused by the 
learning process that has been carried out less facilitating students to train creative thinking of the students.

Based on the explanation above, it can be concluded that the metacognition of students who have high independence only meets the metacognition indicators, namely developing strategies or action plans, controlling or monitoring actions, while in evaluating or evaluating actions there are subjects who have not been able to mention alternatives to solve problems more effectively.

Metacognition of students who have SLR in solving HOTS type problems in the material of flat side space is derived from data from 2 research subjects namely MS1 and MS2 subjects. When compiling an action plan to solve the problem of constructing the flat side space presented, all subjects consisting of 2 students with SLR are doing thinkaloud to the reading activities after the problem is given. Both subjects first read by speaking or reading orally. Then both subjects did a quick reading identified from fastmoving eyes when reading the questions, then realized their thought processes by identifying the information provided in the problem, this is in accordance with opinion from Muaddab (Fitrianti \& Rizal, 2016) which states that planning is a component of the plan of metacognition for identifying and activating abilities in achieving goals.

Later, the two subjects explore the knowledge that they have previously when interpreting the information that has been identified by mentioning the prerequisite knowledge or initial knowledge needed to solve the problem. This can be seen in the following interview results.

$\mathrm{P} \quad$ : Prerequisite material is needed for this. For example, when study factoring, you should first study the rank of material.

MS1: Oh yes Mam, there will be blocks and prisms, which means that the material is square, rectangular, triangular, and Pythagoras theorem.

Q : Why is the material essentially square, rectangular, triangular, and Pythagoras Theorem?

MS1: Because later we will look for the surface area of the beam and prism, Mam.

Although initially, the subject of SLR was having difficulty recalling that initial knowledge, all subjects in this category were able to mention the initial knowledge and the reasons for its use after being given a series of metacognitive questions in the interview. Then the two subjects make predictions about the planned solution that will be done by mentioning the first thing that must be done. In addition, the two subjects were able to mention the concepts to be used in solving problems, namely the concept of building a flat side space and the reasons for using the concept and feeling confident being able to solve the given problem by estimating the time limit needed to solve the problem. When controlling or monitoring their actions, both subjects are of moderate independence, verifying and clarifying their incorrect written answers until the correct answer is obtained when explaining the problem-solving steps by correcting and re-checking the answers. Both subjects realized the mistakes made in solving the problem after being given a series of metacognitive questions and took the initiative to clarify their incorrect written answers by correcting the answers until the correct answers were obtained. This is indicated by the written work of the following MS2 subject which has undergone improvement after the subject realizes an error in the completion procedure (see Fig. 3).

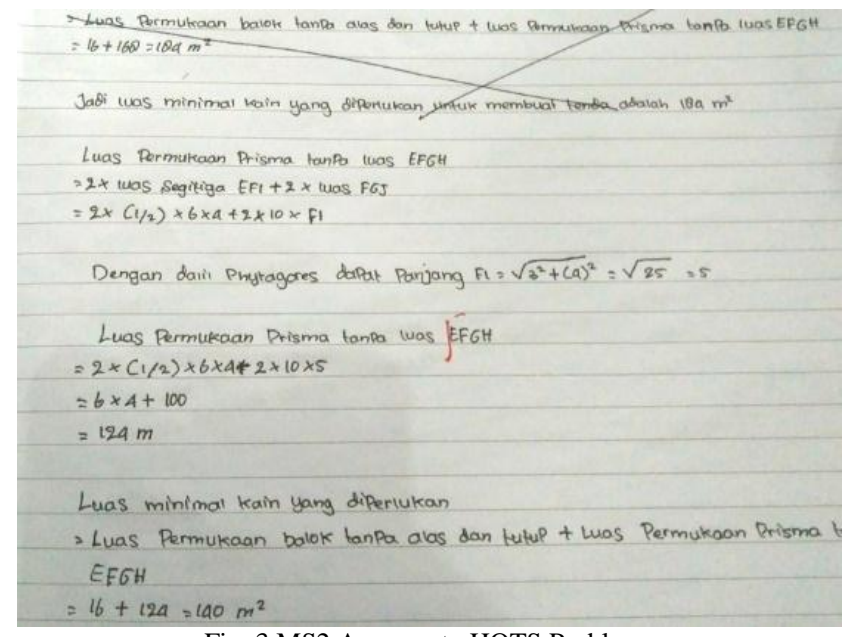

Fig. 3 MS2 Answers to HOTS Problems

Furthermore, the subject identifies important information in the problem so that when solving problems do not make mistakes. The subject identifies the strategy used and classifies related ideas while exploring the reasons for using the strategy when explaining the problem-solving procedure. The subject also developed a solution plan that was compiled by generating new information and stating the problem in the form of drawings. The solution plan that has been prepared previously includes the concept to be used, the first thing to do, and predict the deadline to solve the problem in accordance with what has been done. This shows the planning that has been prepared beforehand, carried out by the subject when solving the problem given so that they are able to interpret the results of the formulation of answers obtained by writing the final conclusions that answer the problem even though not detailed and only in outline only namely writing a minimum area of the fabric to cover tent in accordance with what was asked in the problem. However, there is one medium SLR that has not interpreted the results obtained at the conclusion of the answers, namely the subject MS1 while the subject MS2 is able to interpret the results of the formulation of the answers obtained by writing the final conclusions that answer the problem, this may be due to the most MS1 subjects many make mistakes when solving a given problem compared to other subjects the subject is too focused to make improvements to the results of solving the problem so that it ignores the steps to interpret the final results obtained

When evaluating learning outcomes, a student should reflect on himself by changing his study habits and strategies if necessary, if this is deemed incompatible with the needs of his environment (Risnanosanti, 2008). If it is associated with solving mathematical problems when evaluating the results of solving problems obtained, a student should be able to reflect by changing the steps or strategies used if it is 
deemed unsuitable if applied to the problems needed. In addition, according to Piaget (Amir \& Risnawati, 2016) students who have entered adolescence should have the ability to self-introspection and self-awareness. in solving problems, this ability includes the ability to evaluate its success in solving problems, discard or change strategies to solve problems that are less precise, and can identify alternatives to solve other problems. Subjects with moderate SLR when evaluating their actions identify the strategies used. MS1 subject can mention a more effective settlement step but there is one subject with moderate SLR namely MS2 subject apparently cannot mention alternatives to solve problems more effectively and assume that the steps taken are the most effective steps. Footage of the results of the interview regarding this is as follows.

$\mathrm{Q}$ : In your opinion, are there any more effective remedial steps than this?

MS2: In my opinion, it is okay to use a combination of blocks and prisms. The problem is making me dizzier. So I use trapezoid Mam.

Based on the explanation above, it can be concluded that the metacognition of students who have SLR is only fulfilling the metacognition indicators, namely compiling a strategy or plan of action while in controlling or monitoring the actions there are subjects who have not been able to interpret the results obtained at the conclusion of the answer, namely the subject MS1 and in evaluating or evaluating or judging the actions of there subjects who have not been able to mention alternatives to solve problems more effectively. Metacognition of students who have low SLR in solving HOTS type problems in the material of flat side spaces. Derived from MR1 and MR2 data. When compiling an action plan to solve the problem of constructing the flat side space presented, all subjects consisting of 2 students with low SLR do think-aloud to the reading activities after the problem is given. The two subjects first read aloud (reading aloud), then the two subjects did a quick reading identified from the fast-moving eyes when reading the questions, realized their thought processes by identifying information given in the problem and explaining verbally what was written with sentences that differed, according to the opinion of Pulmones (2007) that planning in solving problems can include thinking and writing what is known and what is not known and identifying where to find information that is not yet known. This can be seen in the written answers of the MR1 subject in Fig. 4.

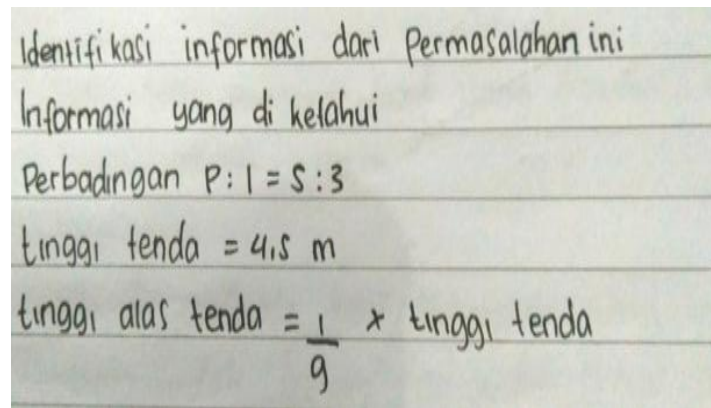

Fig. 4 MR1 Answers to HOTS Problems
When exploring the previously held knowledge when interpreting the information that has been identified, almost all subjects have difficulty remembering the initial knowledge needed to solve the given problem. Only MR1 subjects who were consistently able to explore previously owned knowledge by mentioning the prerequisite knowledge or initial knowledge needed to solve the problem and the reasons for using that initial knowledge, this is different from MR2 subjects who consistently seem to have difficulty digging up prior knowledge they previously had to help him solve problems even though the subject feels capable of solving problems Then students with low SLR make predictions about the planned solution that will be done by mentioning the first thing that must be done. MR2 subjects are not able to mention the concepts that will be used in solving problems but they are confident of being able to solve given problems by estimating the time limit needed to solve the problem. When controlling or monitoring their actions, the two subjects with low SLR, verifying and clarifying their written answers that were not correct until the correct answers were obtained when explaining the steps to solve the problem by making corrections and re-checking answers.

All subjects realized the mistakes made in the results of solving the problem after being given a series of metacognitive questions and taking the initiative to clarify the written answers that were not correct by making corrective answers. Furthermore, the subject identifies important information in the problem so that when solving problems do not make mistakes. The subject identified the strategy used and classified related ideas while exploring the reasons for using the strategy when explaining the problemsolving procedure. The subject also developed a solution plan that was compiled by generating new information and stated the problem in the form of a picture of the subject MR2 was able to carry out a solution plan that had been prepared before when solving the problem which included the concept to be used and the first thing to do even though it was unable to predict the time limit to solve the problem has been done so that the time needed to solve the problem is relatively long as well as the subject of MR2 who is able to carry out the planned solution prepared even though he does not know the concept terms being used, while the subject of MR1 when confirmed through interviews shows that there is a mismatch of the plan with what has been done that is in the first case what must be done when explaining the problemsolving procedure. This shows students are not aware of the previous thought process that has been done when planning a solution that will be done. Though planning is one important part of metacognition because it determines the success of students in solving problems. On the other hand, only MR2 subjects who were consistently able to interpret the results of the formulation of the answers obtained by writing the final conclusions that answer the problem even though it is not detailed and outlines only, namely writing down the minimum surface area of the tent in question in the problem, which is shown in the snippet The results of the MR2 written work can be seen in Fig. 5. 


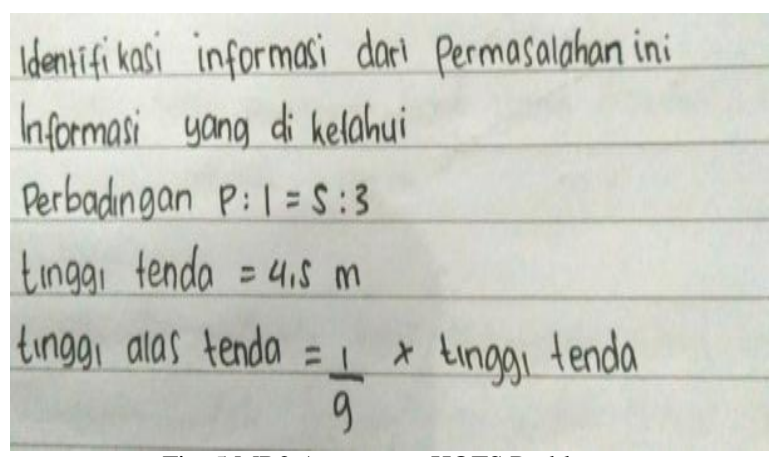

Fig. 5 MR2 Answers to HOTS Problems

When evaluating or assessing their actions, both subjects consistently assess or evaluate the final results of their work correctly. The second is aware of the thought process that is done well when evaluating the results of his written work. Both subjects can evaluate the results of their work well because they are able to assess whether the final results obtained are correct and appropriate or not. When both subjects make mistakes, immediately realize the error after being given a question of metacognition when explaining the problem-solving procedure so that both subjects are able to answer all problems with the correct end result. Both subjects can also evaluate the results of their work because they are able to assess whether the final results obtained are correct and appropriate or not. Both subjects understand when the final result of their work is correct, both subjects will believe that it is indeed true and when the final result obtained is not correct, the subject feels hesitant and unsure of the answer even though the subject has tried to clarify the results of his written work several times make improvements to the answers. Furthermore, when evaluating their actions, subjects with low SLR also find it difficult to identify the strategies used. All subjects with low SLR were unable to mention alternatives to solving problems more effectively and assumed that the steps taken were the most effective steps. This is by the opinion of Kartika, Riyadi, and Sujadi (2015) that students are not aware of the thinking process that is done well when evaluating the results of work in writing because the subject always states that the results of the completion are correct even though there are still errors.

\section{CONCLUSIONS}

Based on the results of data analysis, it can be concluded that: (1) Students who have a high SLR, they used metacognition at the indicator stage to strategize and monitor actions to the maximum. Whereas at the evaluation stage they have not been able to use other alternatives in solving problems more effectively. (2) Students who have SLR were using metacognition to the maximum on the indicators of strategy development. While in monitoring the actions had not been able to interpret the results of the formulation of answers obtained by writing the conclusions of the answers, and in the evaluation, the stage they had not been able to mention other alternatives in solving problems more effectively. (3) Students who have low learning independence had not been able to use metacognition to the maximum.

\section{REFERENCES}

Alfiyah, N., \& Siswono, T. Y. E. (2014). Identifikasi kesulitan metakognisi siswa dalam memecahkan masalah matematika. MATHEdunesa, 3(2), 131138. Retrieved from https://jurnalmahasiswa.unesa.ac.id/index.php/math edunesa

Amir, Z., \& Risnawati. (2016). Psikologi pembelajaran matematika. Yogyakarta: Aswaja Pressindo.

Anggo, M. (2011). The metacognitive process of teacher college students in solving mathematical problem. Proceeding International Seminar and the Fourth National Conference on Mathematics Education Department of Mathematics Education Yogyakarta State University, 368-376. Yogyakarta.

Arifin, Z. (2017). Mengembangkan instrumen pengukur critical thinking skills siswa pada pembelajaran matematika abad 21. Jurnal Theorems (The Original Research of Mathematics), 1(2), 92-100. Retrieved https://jurnal.unma.ac.id/index.php/th

Balk, F. M. A. (2010). The influence of metacognitive questions on the learning process during mathematical tasks in teacher-student conversations: A design study (Utrecht University). Retrieved from https://dspace.library.uu.nl/handle/1874/187079

Bulu, V. R., Budiyono, \& Slamet, I. (2015). Kesulitan metakognisi siswa dalam memecahkan masalah matematika pada materi peluang ditinjau dari tipe kepribadian tipologi hippocrates - galenus kelas XI mia 1 SMA Negeri I SOE. Jurnal Elektronik Pembelajaran Matematika, 3(9), 970-984. Retrieved from http://www.jurnal.fkip.uns.ac.id/index.php/s2math

Desoete, A. (2007). Evaluating and improving the mathematics teaching-learning process through metacognition. Electronic Journal of Research in Educational Psychology, 5(3), 705-730.

Ernawati, E. (2016). Pengembangan perangkat pembelajaran matematika berbasis open-ended approach untuk mengembangkan HOTS siswa SMA. Jurnal Riset Pendidikan Matematika, 3(2), 209-220. Retrieved from https://journal.uny.ac.id/index.php/jrpm

Fitrianti, R. S., \& Rizal, M. (2016). Analisis metakognisi siswa SMP Negeri 1 BUKO dalam memecahkan masalah matematika. Jurnal Mitra Sains, 4, 58-65.

Garrett, A. J., Mazzocco, M. M. M., \& Baker, L. (2006). Development of the Metacognitive Skills of Prediction and Evaluation in Children With or Without Math Disability. Learning Disabilities Research and Practice, 21(2), 77-88. https://doi.org/10.1111/j.1540-5826.2006.00208.x

Kartika, D. L., Riyadi, R., \& Sujadi, I. (2015). Proses metakognisi dalam pemecahan masalah matematika 
pada siswa kelas XI di SMA Negeri Banyumas. Jurnal Pembelajaran Matematika, 3(9), 1021-1034. Retrieved from https://jurnal.fkip.uns.ac.id/index.php/s2math

Kosasih, N. Z., Supratman, S., \& Hermanto, R. (2018). Analisis kesalahan peserta didik dalam menyelesaikan soal pemecahan masalah pada materi aljabar berdasarkan teori Jean Piaget (Penelitian pada peserta didik kelas VIII SMP Islam Al-Azhar 30 Kota Tasikmalaya). JP3M (Jurnal Penelitian Pendidikan Dan Pengajaran Matematika), 4(1), 35-46. Retrieved from http://jurnal.unsil.ac.id/index.php/jp3m/article/view/ NAD41/435

Murtadho, F. (2013). Berpikir kritis dan strategi metakognisi: Alternatif sarana pengoptimalan latihan menulis argumentasi. 2nd Internasional Seminar on Quality and Affordable Education, 530-541. Johor: University Technology Malaysia.

Ormrod, J. E. (2008). Psikologi pendidikan (6th ed.; Indianti, Trans.). Jakarta: Erlangga.

Özsoy, G., \& Ataman, A. (2017). The effect of metacognitive strategy training on mathematical problem solving achievement. International Electronic Journal of Elementary Education, 1(2), 67-82.

Panaoura, A., \& Philippou, G. (2007). The developmental change of young pupils' metacognitive ability in mathematics in relation to their cognitive abilities. Cognitive Development, 22(2), 149-164. https://doi.org/10.1016/J.COGDEV.2006.08.004

Pulmones, R. (2007). Learning chemistry in a metacognitive environment. The Asia-Pacific Education Researcher, 16(2), 165-183. Retrieved from https://ejournals.ph/issue.php?id=373\#prod
Ratnaningsih, N., Akbar, R. R. El, \& Hidayat, E. (2018). Effect of chronotype and student learning time on mathematical ability based on self-regulated learning. Journal of Physics: Conference Series, 1013, 12141. https://doi.org/10.1088/1742$6596 / 1013 / 1 / 012141$

Risnanosanti. (2008). Kemampuan metakognitif siswa dalam pembelajaran matematika. Pythagoras: Jurnal Pendidikan Matematika, 4(1), 86-98. https://doi.org/10.21831/pg.v4i1.690

Schraw, G., Crippen, K. J., \& Hartley, K. (2006). Promoting Self-Regulation in Science Education: Metacognition as Part of a Broader Perspective on Learning. Research in Science Education, 36(1-2), 111-139. https://doi.org/10.1007/s11165-005-39178

Someren, M. W. V., Barnard, Y. F., \& Sandberg, J. A. C. (1994). The think-aloud method: A practical approach to modelling cognitive. London: Academic Press.

Sugiyono. (2017). Metode penelitian kualitatif. Bandung: Alfabeta.

Thomas, A., \& Thorne, G. (2009). How to increase higher order thinking. Retrieved from http://www.studentachievement.org/wpcontent/uploads/How_to_Increase_HOT.doc

Winne, P. H., \& Perry, N. E. (2000). Measuring selfregulated learning. Handbook of Self-Regulation, 531-566. https://doi.org/10.1016/B978-0121098902/50045-7

Zimmerman, B. J. (1990). Self-regulated learning and academic achievement: An overview. Educational Psychologist, 25(1), 3-17. https://doi.org/10.1207/s15326985ep2501_2 